\title{
Anthropogenic factors affecting wild dog Lycaon pictus reintroductions: a case study in Zimbabwe
}

\author{
Harriet T. Davies and Johan T. du Toit
}

\begin{abstract}
In 1997 a pack of African wild dogs Lycaon pictus was reintroduced to Matusadona National Park in north-western Zimbabwe. Here we use this case study to consider anthropogenic factors likely to affect the success of wild dog reintroductions in southern Africa. Potential wild dog-human conflict was investigated using a questionnaire, administered to communal farmers near the Park, that recorded the incidence of livestock predation, snaring, traditional uses and attitudes of local people towards wild dogs. Predation on livestock was negligible, with wild dogs being responsible for $<2 \%$ of goat losses to wild predators. Twenty-four different traditional uses for wild dogs and their body parts were described by $54 \%$ of survey respondents. Less than $25 \%$
\end{abstract}

of survey respondents were aware of the reintroduction, and only $20 \%$ felt positive about it. Recommendations for future wild dog reintroductions include before-and-after public relations and education programmes in neighbouring communities, monitoring to determine actual causes and rates of post-release wild dog mortality and vaccination against canid diseases.

Keywords African wild dogs, case study, humanwildlife interactions, Lycaon pictus, reintroduction, Zimbabwe.

This paper contains supplementary material that can only be found online at http://journals.cambridge.org

\section{Introduction}

Translocations and introductions of threatened species face challenges that go beyond the usual biological, ecological and technical problems (Reading et al, 1997). Large carnivores are confronted by deeply ingrained antipathy amongst rural traditional societies, and carnivore reintroductions face particular problems that are not always related to predation on livestock (Yalden, 1993). In Zimbabwe wild dogs Lycaon pictus were considered stock killers, and first classified as vermin in 1916. A bounty was offered between 1916 and 1975, by which time more than 3,400 animals had been killed under the auspices of vermin control (Childes, 1988). Their populations have been decimated and, although their vermin status has been rescinded and they are now legally protected, wild dogs continue to be persecuted in Zimbabwe and other parts of Africa (Childes, 1988; Ginsberg et al., 1995; van Heerden et al., 1995; Rasmussen, 1997;

Harriet T. Davies ${ }^{1}$ (Corresponding author) Tropical Resource Ecology Programme, University of Zimbabwe, P.O Box MP 167, Harare, Zimbabwe. Email harriet@limpopo.co.za

Johan T. du Toit Mammal Research Institute, Department of Zoology and Entomology, University of Pretoria, Pretoria 0002, South Africa.

${ }^{1}$ Present address: Wildlife Conservation Research Unit, Department of Zoology, University of Oxford, Oxford, OX1 3PS, UK.

Received 15 April 2002. Revision requested 27 November 2002. Accepted 20 June 2003.
Woodroffe \& Ginsberg, 1997a). Furthermore, anthropogenic impacts on wild dogs extend into protected areas. For example in Hwange National Park, Zimbabwe, snaring and shooting have been found to contribute $29 \%$ of wild dog mortality (Ginsberg et al., 1995). In Kruger National Park, South Africa, snaring was found to be the second most important cause of adult mortality (21\%; van Heerden et al., 1995). L. pictus is categorized as Endangered on the IUCN Red List (IUCN, 2002).

One way to mitigate human-wild dog conflict is to move wild dogs out of areas in which they are at high risk. Whether this can be done depends on the availability of areas suitable for the establishment of viable populations from founder packs (Woodroffe \& Ginsberg, 1997b). Several wild dog translocations and reintroductions have been made, with varying degrees of success (Childes, 1988; English et al., 1993; Scheepers \& Venzke, 1995). One such translocation took place in Zimbabwe in mid 1997. In response to demands from cattle ranchers in the Nyamandhlovu region of Matebeleland, the Department of National Parks and Wildlife Management used a helicopter-assisted boma capture technique (English et al., 1993) to catch 11 of the 14 dogs in the targeted pack, which they immediately transported by road to an enclosure on Fothergill Island in Lake Kariba, part of Matusadona National Park. They were later released into the main part of the Park. A combination of post-release radio-collar failure and dispersal of individuals from the park prevented long-term monitoring of the released 
individuals. None of the released individuals were seen within the study area subsequent to the 1998 breeding season, and while the outcome of the translocation is unknown, it is unlikely that it was a success.

This paper reports on a post-release study of people's attitudes towards the wild dog reintroduction, focusing on Omay Communal Land, the settled area that isolates the Park from other wildlife areas. We examine how these attitudes may have affected the survival of wild dogs in this area and the implications of this for other potential wild dog reintroductions and translocations in southern Africa.

\section{The study area}

Matusadona National Park is situated on the southern shore of Lake Kariba in northern Zimbabwe. The $1,370 \mathrm{~km}^{2}$ Park is bounded by the Ume and Sanyati Rivers to the west and east respectively. A rugged escarpment, the Matusadona Hills, is separated from a lakeshore grassland belt by an area of flat woodland. The $2,870 \mathrm{~km}^{2}$ of Omay Communal Land in Nyaminyami District surrounds the inland boundaries of the Park (Taylor, 1993a). Omay has a population of $>19,000$ in four chieftanships: Mola, Negande, Nebiri and Msampakaruma (Taylor, 1993a). Land-use centres around subsistence cultivation. Due to the presence of tsetse fly (Glossina spp.) cattle have been excluded from the area until recently and goats comprise the majority of livestock holdings (Taylor, 1993a). Large wild herbivore populations in Omay Communal Land are typical of the Zambezi Valley (Taylor, 1993a), and carnivore populations consist of lion Panthera leo, leopard Panther pardus, spotted hyaena Crocuta crocuta and side-striped jackal Canis adustus (Taylor, 1993a). Historically, wild dog sightings in the Park and Omay Communal Land were so rare that the species was not even listed as vagrant for the area (Childes, 1988; Davies, 1992; Woodroffe et al., 1997). Nyaminyami District participates in the Communal Areas Management Programme for Indigenous Resources (CAMPFIRE; Child, 1996) and in January 1989 was one of the first districts to receive 'appropriate authority' status to manage its wildlife resources (Taylor, 1993a). The Nyaminyami Wildlife Management Trust was established in 1988. Through CAMPFIRE, the Trust is charged with the administration and management of natural resources for the benefit of the people living in the area.

\section{Methods}

A questionnaire was administered to local people in Omay Communal Land in June and July 1998 (Appendix 1 ). The survey consisted of a series of questions about wild dog and wildlife-related issues pertinent to the communal land farmer. Prevalence of livestock, predation by wild animals, methods of anti-predator control, prevalence of domestic dogs in the area, local traditional uses of wild dogs, public perception of wild dogs and knowledge of the 1997 translocation were all investigated. Six wards sharing their borders with Matusadona National Park were chosen for this study. Four or five household clusters, comprising one or more households living in close proximity, were surveyed within each Village Development Committee in the six wards. Two enumerators, chosen on the basis of their familiarity with the area, the language and the issues being explored, were employed to administer the questionnaires. Where possible, questionnaires were administered to groups of people, rather than individuals. These groups were loose gatherings of household members, not separated by gender or age. A representative response was recorded for each household cluster. To avoid influencing the responses, we did not participate in the administration of questionnaires.

\section{Results}

\section{Respondent details}

A total of 93 household clusters were sampled (34 in Mola Wards A and B, 31 in Nebiri Wards A and B, and 28 in Msampakaruma Wards A and B), containing a total of 402 households. The mean number of households in each cluster was 4.3. Livestock were kept by all 93 respondents, including cattle (in Nebiri and Msampakaruma, which are tsetse-free areas), donkeys, goats, sheep, pigs, chickens, dogs, cats, pigeons, ducks and guinea fowl (Table 1). Chickens, goats and donkeys, in that order, were the most prevalent domestic animals in the district.

Table 1 The percentage of village clusters keeping various livestock species in three Chieftanships of Omay Communal Land during 1997, arranged from the most commonly kept species overall.

\begin{tabular}{lcccc}
\hline & \multicolumn{3}{c}{ Percentage of respondents stocking each species } \\
\cline { 2 - 5 } $\begin{array}{l}\text { Livestock } \\
\text { species }\end{array}$ & $\begin{array}{l}\text { Mola } \\
(\mathrm{n}=34)\end{array}$ & $\begin{array}{l}\text { Nebiri } \\
(\mathrm{n}=31)\end{array}$ & $\begin{array}{l}\text { Msampakaruma } \\
(\mathrm{n}=28)\end{array}$ & $\begin{array}{c}\text { Overall } \\
(\mathrm{n}=93)\end{array}$ \\
\hline Chicken & 100 & 100 & 100 & 100 \\
Goat & 91 & 97 & 93 & 94 \\
Donkey & 29 & 100 & 93 & 72 \\
Dog & & 61 & 57 & 38 \\
Duck & & 42 & 36 & 25 \\
Cattle & & 35 & 39 & 24 \\
Cat & & 19 & 18 & 12 \\
Pigeon & & 13 & & 8 \\
Sheep & 9 & 6 & 14 & 3 \\
Guinea fowl & & 10 & &
\end{tabular}




\section{The potential for wild dog-human conflict: livestock predation, snaring and disease}

Predation of livestock by wild animals was ubiquitous, with all respondents reporting losses to a number of different predators (Table 2). Wild cats Felis lybica were the most prevalent problem animals $(85 \%$ of respondents reported losses to wild cats) but lions were perceived as the biggest problem, probably because they took the largest and most valuable animals (cattle, donkeys and goats; Table 2). The perceived threat of lion predation reflected the proportion of respondents keeping large livestock in each ward, being highest in Nebiri and Msampakaruma where large stock were widespread, and lowest in Mola where large stock was less prevalent. Wild dogs were reported as the most serious problem animal by only 5 out of 93 village clusters and were held responsible for the loss of only 10 goats during 1997 . Wild dogs were not held responsible for losses of other livestock species. Although wild dogs were perceived as the most serious predator of domestic livestock after lions and wild cats (Table 3), overall losses of goats to wild dogs were less than to lions, baboons Papio cynocephalus ursinus, leopards, hyaenas, crocodiles Crocodilus niloticus and snakes during 1997 (Table 2). Three of the five respondents who labeled wild dogs as the biggest problem reported losses that had taken place during 1998. It is possible that these losses were due to the released pack. However, respondents reported a total of 39 different wild dog sightings and 19 of these took place before 1997, with some dating back more than 30 years. Post-1997 sightings were most numerous in Nebiri area, where wild dogs were seen 14 times by respondents in 10 villages.

Respondents used a combination of anti-predator strategies, and these varied according to the type of livestock that was kept. In Nebiri and Msampakaruma Wards where cattle and donkeys are widely stocked, strong paddocks and herding during the day were the most commonly employed methods. In Mola, where

Table 2 Reports of livestock losses to wild predators in three Chieftanships of Omay Communal Land, combined, during 1997.

\begin{tabular}{|c|c|c|c|c|c|c|c|}
\hline \multirow[b]{2}{*}{ Predator species } & \multicolumn{7}{|c|}{ Number of losses reported for each livestock species } \\
\hline & Chicken & Goat & Donkey & Dog & Duck & Cattle & Sheep \\
\hline Baboon Papio ursinus & 114 & 148 & & & & & \\
\hline Cheetah Acinonyx jubatus & & 4 & & & & & \\
\hline Crocodile Crocodilus niloticus & & 18 & 6 & & & & \\
\hline Eagle & 225 & & & & & & \\
\hline Honey badger Mellivora capensis & 224 & & & & & & \\
\hline Hyaena Crocuta crocuta & & 41 & 3 & 7 & 7 & & \\
\hline Jackal Canis adustus & 24 & 3 & & 6 & 3 & & \\
\hline Leopard Panthera pardus & & 44 & & 3 & 3 & & \\
\hline Lion Panthera leo & & 282 & 115 & & & 3 & 8 \\
\hline Snakes & 9 & 16 & 2 & & & & \\
\hline Wild cat Felis lybica & 441 & & & & 7 & & \\
\hline Wild dog Lycaon pictus & & 10 & & & & & \\
\hline
\end{tabular}

Table 3 The number and percentage of communal land farmers labelling individual wildlife species as the biggest problem animal in three Chieftanships of Omay Communal Land during 1997. Predators are presented in order of overall importance.

\begin{tabular}{|c|c|c|c|c|c|c|c|c|}
\hline \multirow[b]{2}{*}{ Predator species } & \multicolumn{2}{|l|}{ Mola } & \multicolumn{2}{|c|}{ Nebiri } & \multicolumn{2}{|c|}{ Msampakaruma } & \multicolumn{2}{|l|}{ Total } \\
\hline & No. & $\%$ & No. & $\%$ & No. & $\%$ & No. & $\%$ \\
\hline Lion & 2 & 6 & 26 & 84 & 21 & 75 & 49 & 53 \\
\hline Wild cat & 27 & 79 & & & & & 27 & 29 \\
\hline Wild dog & & & 4 & 13 & 1 & 4 & 5 & 5 \\
\hline Baboon & $1.5^{*}$ & 4 & & & 2 & 7 & $3.5^{*}$ & 4 \\
\hline Hyaena & & & & & 3 & 11 & 3 & 3 \\
\hline Leopard & & & & & 1 & 4 & 1 & 1 \\
\hline Crocodile & & & 1 & 3 & & & 1 & 1 \\
\hline Snake & 1 & 3 & & & & & 1 & 1 \\
\hline Jackal & $0.5^{*}$ & 1 & & & & & $0.5^{*}$ & 1 \\
\hline No response & 2 & 6 & & & & & 2 & 2 \\
\hline Totals & 34 & 100 & 31 & 100 & 28 & 100 & 93 & 100 \\
\hline
\end{tabular}

*Where two species were named as the biggest problem, each was given half a point. 
chickens and goats are the predominant livestock species, fencing was a more important anti-predator strategy. Other methods included keeping domestic dogs to alert villagers to the presence of wild animals, planting thorn bushes around kraals, killing the predators (by ambush or use of poison and guns) and reporting the problem animals to the District Council.

All respondents felt they should be compensated for livestock losses to wild animals. In 57 household clusters it was felt that the Nyaminyami Rural District Council should be held responsible for compensation. The prevailing attitude was that the Council owns, is responsible for, and benefits from wildlife and natural resources in the area; the Council arrests or fines people caught killing wild animals and hence must accept responsibility for the damage caused by wildlife. Thirty respondents laid responsibility for compensation with the Department of National Parks and Wildlife Management, one respondent with their ward development committee, one with the CAMPFIRE programme and four with the government in general. In most cases, the reasons for holding a particular authority responsible were similar to those given for the Nyaminyami Rural District Council .

Despite the establishment in 1990 of a district level paramilitary uniformed ranger force, a large number of snares were set by people living in Omay. During the period January 1990 to June 1992, the number of monthly anti-snare patrols decreased from a peak of 13 to one, while the number of snares recovered increased (Taylor, 1993b). There has been no subsequent research and the frequency of snaring during 1993-1998 is not known. Reports of the Nyaminyami Rural District Council patrols for November 1995 to July 1998 suggest, however, that the incidence of snaring is high in the communal lands neighbouring the Park. In addition to snares recovered by Council Game Scouts, safari operators have found numerous snare lines in the area (Anon., 1998). Although the target is usually meat-providing species such as impala Aepyceros melampus, kudu Tragelaphus strepsiceros and buffalo Syncerus caffer, a wide variety of animals are found trapped in snares, from elephants Loxodonta africana and lions to smaller species such as duiker Sylvicapra grimmia, Sharpe's grysbok Raphicerus sharpei and game birds such as helmeted guineafowl Numida meleagris (Nyaminyami Rural District Council patrol records for 1995-1998).

Domestic dogs Canis familiaris were found throughout the study area, and their distribution did not differ significantly between wards. Eighty-four percent of respondents reported the presence of at least one domestic dog in their village settlement. Assuming an average of 4.79 people per household (Central Statistics Office, 1992) the overall domestic dog:human ratio was 1:5.9, with an average number of $1.23 \pm$ SE 0.19 domestic dogs per household. These data are consistent with findings from previous studies on domestic dogs in Zimbabwean communal lands (Butler, 1998; Butler \& du Toit, 2002).

\section{Traditional uses of wild dogs and their parts}

Fifty-four percent of the respondents reported knowledge of traditional uses for wild dogs (Table 4). Fifteen out of 24 uses were consumptive, i.e. the wild dog must be killed to obtain the required product, and nine were non-consumptive. Other non-consumptive products encompassed wild dog-based belief systems: for example, several respondents stated that if wild dogs hunted near a settlement and villagers put salt on the carcass remains, the wild dogs would drive prey towards the village in their next hunt. Wild dog products were obtained in a number of ways (Table 5), the most common of which was from animals that had been snared or poisoned.

The value of the wild dog totem, ganyani, is highly variable. Only 29\% of the 27 respondents familiar with the wild dog totem felt that extinction of wild dogs would have negative impacts on totem holders. These included heart problems and the fact that the spirit mediums of wild dogs could not continue to exist if the animals became extinct. On the other hand, reasons why wild dog extinction would not affect totem holders revolved primarily around the idea that totems are merely beliefs and do not reside in human bodies.

\section{Public perception of the 1997 wild dog translocation}

At the time of this study only $24 \%$ of household clusters were aware of the 1997 wild dog introduction to the Park (Table 6). Knowledge about the translocation varied among sites ( $\chi^{2}$-test, $\mathrm{P}=0.011,2$ d.f.), with more respondents in Mola reporting knowledge than in the other two areas. Peoples' attitudes towards having wild dogs in their area were generally negative and only $20 \%$ of respondents indicated that they felt good about having wild dogs around. The distribution of positive, negative and neutral responses were similar in all three study sites and attitudes assessed did not appear to be related to awareness of the introduction. Respondents provided a number of reasons to justify their attitudes towards wild dogs (Table 7). Reasons for feeling positive towards wild dogs included the fact that they do not disturb people, they are regarded as holy and that people enjoy the meat from carcasses left by wild dogs. A positive response came from three respondents in Mola who indicated that they wanted wild dogs around so that their children could benefit from the experience of wild dogs. Negative attitudes towards wild dogs were fuelled primarily by fear for livestock and humans. One respondent felt that wild dogs kill other, more lucrative, game species and 
Table 4 Details of the various uses for different wild dog parts reported by people living in three Chieftanships of Omay Communal Land during 1997.

\begin{tabular}{|c|c|c|c|c|c|}
\hline \multirow[b]{2}{*}{ Wild dog body part } & \multirow[b]{2}{*}{ Uses } & \multicolumn{4}{|c|}{ Number of respondents reporting a particular use } \\
\hline & & Mola & Nebiri & Msampakaruma & Overall \\
\hline \multirow[t]{5}{*}{ Faeces } & Cures those suffering dizziness & & & 3 & 3 \\
\hline & Given to domestic dogs so they hunt better & 2 & & & 2 \\
\hline & Used to treat tetanus & & 2 & & 2 \\
\hline & Used for farming magic & 1 & & & 1 \\
\hline & Given to young babies & 1 & & & 1 \\
\hline \multirow[t]{2}{*}{ Teeth } & Ground and fed to dogs to make them cheeky & 4 & 1 & & 5 \\
\hline & $\begin{array}{l}\text { Used to make young peoples' teeth strong } \\
\text { (before there were clinics) }\end{array}$ & 1 & & & 1 \\
\hline Meat & Given to domestic dogs so they run faster & 1 & & & 1 \\
\hline \multirow[t]{4}{*}{ Magical } & Wild dogs drive animals to peoples homes & & 1 & 2 & 3 \\
\hline & $\begin{array}{l}\text { If one puts salt on meat left after a wild dog kill, } \\
\text { (before there were clinics) will bring meat to the village }\end{array}$ & 2 & & 1 & 3 \\
\hline & Witches travel on them during night & 2 & & & 2 \\
\hline & Considered holy & 1 & 1 & & 2 \\
\hline \multirow[t]{2}{*}{ Heart } & Fed to domestic dogs so they hunt faster & 2 & & & 2 \\
\hline & Eaten by hunters to make them brave & & & 1 & 1 \\
\hline \multirow[t]{3}{*}{ Fat } & Used to treat tetanus & & 3 & 4 & 7 \\
\hline & Used to bring good luck & 3 & & 1 & 4 \\
\hline & Used to make one feared & 1 & & 1 & 2 \\
\hline Tail & $\begin{array}{l}\text { End of tail fed to domestic dogs to make them run faster (and } \\
\text { tracked animal loses power) }\end{array}$ & & 5 & & 5 \\
\hline Nose & Fed to domestic dogs so they hunt better & & 3 & 3 & 6 \\
\hline Nails & Fed to domestic dogs so they hunt better & & & 4 & 4 \\
\hline Brain & Fed to domestic dogs so they hunt better & & 3 & 1 & 4 \\
\hline \multirow[t]{3}{*}{ Skin } & Used for clothing during festivals & & 3 & 4 & 7 \\
\hline & Middle of head skin for witchdoctors' clothing & & 2 & & 2 \\
\hline & Used to treat scratches and injuries & 1 & & & 1 \\
\hline \multicolumn{2}{|c|}{ Number of different household clusters reporting at least one use } & 18 & 14 & 18 & 50 \\
\hline \multicolumn{2}{|c|}{ Number of different types of uses reported } & 13 & 10 & 11 & 24 \\
\hline
\end{tabular}

Table 5 Different methods employed by residents of three Chieftanships of Omay Communal Land during 1997 to obtain wild dog products, and the number of respondents reporting each method.

\begin{tabular}{|c|c|c|c|c|c|}
\hline \multirow[b]{2}{*}{ Product(s) } & \multirow[b]{2}{*}{ Methods used to obtain products } & \multicolumn{4}{|c|}{ Number of respondents reporting each method } \\
\hline & & Mola & Nebiri & Msampakaruma & Total \\
\hline \multirow{5}{*}{$\begin{array}{l}\text { Consumptive } \\
\text { (e.g. flesh, skin) }\end{array}$} & Find a dead wild dog & 11 & & & 11 \\
\hline & Find a trapped wild dog & 1 & & & 1 \\
\hline & Killing wild dogs* & 1 & 18 & 12 & 31 \\
\hline & Poisoning & 1 & 1 & & 2 \\
\hline & Snaring & & 17 & 11 & 28 \\
\hline \multirow[t]{2}{*}{ Faeces } & Find in forest & 3 & & & 3 \\
\hline & Track with domestic dogs & & & 2 & 2 \\
\hline Witches travel & Use magic & 1 & & & 1 \\
\hline Meat of prey brought to the village & Live wild dogs attracted with salt & 2 & & & 2 \\
\hline
\end{tabular}

*Killing has been divided into poisoning and snaring where such details were provided by respondents.

in doing so, reduce the districts' ability to generate revenue from CAMPFIRE activities.

\section{Discussion}

Data from our post-release survey suggest that potentially significant threats to wild dogs exist in the communal land surrounding Matusadona National Park. These threats, which include both accidental and deliberate anthropogenic impacts as well as indirect factors that may limit wild dog numbers, may have led to the disappearance of the pack. Accidental anthropogenic impacts include the incidence of road accidents involving wild dogs, and mortality from snares set for other animals. No 
Table 6 Responses to questions (see Appendix) concerning wild dog conservation and people's attitudes, in three Chieftanships of Omay Communal Land during 1997, towards the introduction of wild dogs into Matusadona National Park.

\begin{tabular}{|c|c|c|c|c|}
\hline \multirow[b]{2}{*}{ Question } & \multicolumn{4}{|c|}{ Number of positive responses (percentage) } \\
\hline & Mola & Nebiri & Msampakaruma & Total \\
\hline \multicolumn{5}{|l|}{ Knowledge about threatened status of wild dogs? } \\
\hline Yes & $9(26)$ & $\mathrm{NDA}^{*}$ & NDA & $9(26)$ \\
\hline No & $25(74)$ & $\mathrm{NDA}^{*}$ & NDA & $25(74)$ \\
\hline \multicolumn{5}{|l|}{ Knowledge of the translocation? } \\
\hline Yes & $14(41)$ & $5(16)$ & $3(11)$ & $22(24)$ \\
\hline Informed by Matusadona National Park & 11 & 4 & 3 & 18 \\
\hline Informed by Hwange National Park & 1 & & & 1 \\
\hline Informed by school & 1 & & & 1 \\
\hline Heard through rumours & & 1 & & 1 \\
\hline Gave no information & 1 & & & 1 \\
\hline No & $20(59)$ & $26(84)$ & $24(86)$ & $70(75)$ \\
\hline No response & & & $1(3)$ & $1(1)$ \\
\hline \multicolumn{5}{|c|}{ Attitude towards the presence of wild dogs in the area } \\
\hline Positive & $6(18)$ & $8(26)$ & $5(18)$ & $19(20$ \\
\hline Negative & $27(79)$ & $23(74)$ & $22(79)$ & $72(78)$ \\
\hline Neutral & $1(3)$ & & & $1(1)$ \\
\hline No response & & & $1(3)$ & $1(1)$ \\
\hline Totals & 34 & 31 & 28 & 93 \\
\hline
\end{tabular}

*NDA, no data available.

Table 7 Reasons given by people in three Chieftanships of Omay Communal Land during 1997 to justify their attitudes towards the presence of wild dogs in the area. Some respondents provided more than one justification for their attitude.

\begin{tabular}{|c|c|c|c|c|c|c|}
\hline \multirow{2}{*}{$\begin{array}{l}\text { Attitude } \\
\text { towards } \\
\text { wild dogs }\end{array}$} & \multirow[b]{2}{*}{ Reasons given to justify attitude towards wild dogs } & \multicolumn{4}{|c|}{ Number of positive responses } & \multirow{2}{*}{$\begin{array}{l}\text { Percentage of } \\
\text { respondents } \\
(n=93)\end{array}$} \\
\hline & & Mola & Nebiri & Msampakaruma & Total & \\
\hline \multirow[t]{7}{*}{ Positive } & We enjoy the meat from wild dog kills & & 8 & 5 & 13 & 14 \\
\hline & Wild dogs do not disturb people & 1 & 5 & 6 & 12 & 13 \\
\hline & Wild dogs keep other predators away from the village & & 6 & & 6 & 6 \\
\hline & Those possessed with spirits regard wild dogs as holy & & & 4 & 4 & 4 \\
\hline & So that our children can see wild dogs in the future & 3 & & & 3 & 3 \\
\hline & Wild dogs do not disturb livestock & 2 & & & 2 & 2 \\
\hline & People could tame wild dog pups & & 1 & & 1 & 1 \\
\hline Neutral & We are used to wild animals & 1 & & & 1 & 1 \\
\hline \multirow[t]{10}{*}{ Negative } & Wild dogs harm livestock & 23 & 22 & 19 & 64 & 69 \\
\hline & Wild dogs harm people & 5 & 12 & 11 & 28 & 30 \\
\hline & We are afraid of wild dogs & 1 & 13 & 10 & 24 & 26 \\
\hline & Wild dogs harm domestic dogs & 1 & 1 & 1 & 3 & 3 \\
\hline & Wild dogs bring other predators to the village & 1 & 1 & & 2 & 2 \\
\hline & Wild dogs kill wildlife and therefore reduce CAMPFIRE earnings & & 1 & & 1 & 1 \\
\hline & Wild dogs are hard to control as domestic dogs do not bark at them & & & 1 & 1 & 1 \\
\hline & Wild dogs spread rabies to dogs and people & 1 & & & 1 & 1 \\
\hline & Wild dogs threaten lions and hyaenas & & & 1 & 1 & 1 \\
\hline & Wild dog totems do not stay in human bodies & 1 & & & 1 & 1 \\
\hline
\end{tabular}

major high-speed roads pass through the Omay Communal Land, and therefore the risk of road accident deaths is negligible, but there are substantial risks posed by snaring. In Hwange National Park, snares are responsible for $10 \%$ of adult wild dog deaths (Ginsberg et al., 1995), and it has been postulated that in smaller parks such as Matusadona National Park, where pack home range areas are more likely to extend across park boundaries, snaring may be even more of a problem (van Heerden et al., 1995).

Deliberate threats take the form of poisoning or snaring of wild dogs, either for livestock protection or for harvesting of wild dog products. Although wild dogs have been held responsible for relatively few livestock losses in the past, any increase in wild dog density brought about by a successful reintroduction programme 
is likely to lead to a corresponding increase in actual and/or perceived stock losses. Wild dog persecution under the pretext of stock protection would therefore also be expected to rise. Deliberate snaring of wild dogs for consumptive products constitutes an important potential threat to any introduced wild dog pack. Wild dogs present a range of potential values and uses to people living near the Park. Combined with the fact that the majority of survey respondents displayed negative attitudes towards wild dogs, this indicates a predisposition for people to kill wild dogs ranging in Omay Communal Land.

Indirect anthropogenic impacts include the transmission of diseases from domestic dogs (Alexander \& Appel, 1994; Kat et al., 1995). Intuitively, wild dog populations that are small or isolated, that occur near human settlements, and that have not been exposed to diseases common in sympatric domestic dogs, are likely to be those most at risk from disease outbreaks. In the case of the wild dogs translocated into Matusadona National Park, it appears that disease risks are substantial for several reasons. Firstly, apart from migrant wild dogs that enter the area from time to time (Childes, 1988; Davies, 1992), the translocated pack represents the entire population of the area. If one wild dog in the pack becomes infected, the survival of the entire population will be jeopardized. Secondly, this is a small Park completely surrounded by communal lands. Any movement of wild dogs from the park must be into areas where domestic dogs reside and where the probability of meetings between wild and domestic dogs is high. Thirdly, while none of the introduced wild dogs had been previously exposed to rabies, $19 \%$ of domestic dogs sampled in the communal lands were seropositive to the disease (Davies, 1998).

The potential threats discussed above occur against a backdrop of ignorance and poor public relations. Although public relations and education programmes do not in themselves increase the success of translocations of threatened species, perceived local support for translocation programmes appears to be correlated to translocation success (Reading et al., 1997). No public relations or education programmes were incorporated into the 1997 wild dog translocation to Matusadona National Park and as a result, even 1 year after the exercise, few people in Omay Communal Land were aware that wild dogs had been moved into the area. It is not clear why respondents in Mola were significantly more knowledgeable about the release than their counterparts in Msampakaruma and Nebiri. However, greater awareness did not translate into more favourable attitudes towards wild dogs.

Although feasibility assessments should ideally be completed prior to introductions of threatened species, the translocation of wild dogs to Matusadona National
Park was essentially an emergency rescue operation, and a detailed pre-translocation assessment of the suitability of the Park as a release site was not possible. Our examination of the likely threats to wild dogs in the area suggests that several anthropogenic factors could have led to the disappearance of the released pack. It may have been possible to mitigate some of the factors identified in this paper: reducing conflict by developing suitable husbandry strategies to protect livestock (Kruuk, 1980, cited in Mills, 1991), protecting individual wild dogs from snaring by fitting them with anti-snare collars, and reducing risk of disease transmission by vaccinating local domestic dog populations. In addition, emphasizing the non-consumptive uses of wild dogs such as their magical and mythical uses and by-products such as faeces, and ecotourism, could also reduce the potential for conflict by creating economic benefits to local human communities.

The quality of the release site is one of the most important determinants of carnivore reintroduction or translocation success (Linnell et al., 1997), and in particular it is important that previous causes of local extinction no longer exist (Woodroffe \& Ginsberg, 1999). The virtual absence of wild dogs in the Matusadona-Omay system prior to the 1997 release (Childes, 1988; Davies, 1992; Woodroffe et al., 1997) strongly suggests that there are limiting factors that will continue to prevent the successful establishment of wild dogs there in the long-term. Identification of these factors prior to translocation could have prevented the expenditure of both time and money on a venture that always had a tenuous likelihood of success.

\section{Acknowledgements}

For assistance with the administration of questionnaires we thank T. Chamboko, T. Chiyandamali and I. Siabwanda. Mr. Hove and Mr. Msonza of Nyaminyami Rural District Council facilitated the survey; J. Jackson and M. Murphree assisted with methodological aspects. T. McNutt and an anonymous referee provided helpful comments on the manuscript. This research was supported by the Zambezi Society, Shearwater (Pvt) Ltd., WISDOM Institute and Fothergill Island Safari Lodge. The latter also provided invaluable logistical support, as did the staff of Matusadona National Park.

\section{References}

Alexander, K.A. \& Appel, M.J.G. (1994) African wild dogs (Lycaon pictus) endangered by a canine distemper epizootic among domestic dogs near the Masai Mara National Reserve, Kenya. Journal of Wildlife Diseases, 30, 481-485.

Anon. (1998) Snares pose serious threat to jumbos. The Sunday Mail, 12 April 1998. 
Butler, J.R.A. (1998) The ecology of communal land dogs in Zimbabwe. PhD thesis, University of Zimbabwe, Zimbabwe.

Butler, J.R.A \& du Toit, J.T. (2002) Diet of free-ranging domestic dogs (Canis familiaris) in rural Zimbabwe: implications for wild scavengers on the periphery of wildlife reserves. Animal Conservation, 5, 29-37.

Central Statistics Office (1992) 1992 Census: Zimbabwe Preliminary Report. Central Statistics Office, Harare, Zimbabwe.

Child, B. (1996) The practice and principles of community-based wildlife management in Zimbabwe: the CAMPFIRE programme. Biodiversity and Conservation, $\mathbf{5}$ 369-398.

Childes, S.L. (1988) The past history, present status and distribution of the hunting dog Lycaon pictus in Zimbabwe. Biological Conservation, 44, 301-316.

Davies, C. (1992) Status of Lycaon in Zimbabwe. Unpublished Report, Workshop on the Conservation and Recovery of the African Wild Dog, Lycaon pictus, Arusha, Tanzania.

Davies, H.T. (1998) The suitability of Matusadona National Park, Zimbabwe, as a site for wild dog (Lycaon pictus) introduction. MSc thesis, University of Zimbabwe, Zimbabwe.

English, R.A., Stalmans, M., Mills, M.G.L. \& van Wyk, A. (1993) Helicopter-assisted boma capture of African wild dogs Lycaon pictus. Koedoe, 36,103-106.

Ginsberg, J.R., Alexander, K.A., Creel, S., Kat, P.W., McNutt, J.W. \& Mills, M.G.L. (1995) Handling and survivorship of African wild dog (Lycaon pictus) in five ecosystems. Conservation Biology, 9, 665-674.

IUCN (2002) 2002 IUCN Red List of Threatened Species. IUCN, Gland, Switzerland [http://www.redlist.org, accessed 4 November 2003].

Kat, P.W., Alexander, K.A., Smith, J.S. \& Munson, L. (1995) Rabies and African wild dogs in Kenya. Proceedings of the Royal Society of London Series B, 262, 229-233.

Linnell, J.C.C., Aanes, R., Swenson J.E., Odden, J. \& Smith, M.E. (1997) Translocating carnivores as a method for managing problem animals: a review. Biodiversity and Conservation, $\mathbf{6}$, 1245-1257.

Mills, M.G.L. (1991) Conservation management of large carnivores in Africa. Koedoe, 34, 81-90.

Rasmussen, G.S.A. (1997) Conservation Status of the Painted Hunting Dog Lycaon pictus in Zimbabwe. DNPWLM/ Painted Dog Research Project, Harare, Zimbabwe.

Reading, R.P., Clark, T.W. \& Griffith, B. (1997) The influence of valuational and organisational considerations on the success of rare species translocations. Biological Conservation, 79, 217-225.

Scheepers, J.L. \& Venzke, K.A.E. (1995) Attempts to reintroduce African wild dogs Lycaon pictus into Etosha National Park, Namibia. South African Journal of Wildlife Research, 25, 138-140.

Taylor, R.D. (1993a) Elephant Management in Nyaminyami District, Zimbabwe: Turning a Liability into an Asset. Multispecies Animal Production Systems Project, Project Paper No. 33. WWF, Harare, Zimbabwe.
Taylor, R.D. (1993b) Wildlife Management and Utilisation in a Zimbabwean Communal Land: A Preliminary Evaluation in Nyaminyami District, Kariba. Multispecies Animal Production Systems Project, Project Paper No. 32. WWF, Harare, Zimbabwe.

van Heerden, J., Mills, M.G.L., van Vuuren, M.J., Kelly, P.J. \& Dreyer, M.J. (1995) An investigation into the health status and diseases of wild dogs (Lycaon pictus) in the Kruger National Park. Journal of the South African Veterinary Association, 66, 18-27.

Woodroffe, R. \& Ginsberg, J.R. (1997a) Past and future causes of wild dogs' population decline. In The African Wild Dog-Status Survey and Conservation Action Plan (eds R. Woodroffe, J.R. Ginsberg \& D. Macdonald), pp. 58-74. IUCN/Species Survival Commission Canid Specialist Group, IUCN, Gland, Switzerland.

Woodroffe, R. \& Ginsberg, J.R. (1997b) The role of captive breeding and reintroduction in wild dog conservation. In The African Wild Dog-Status Survey and Conservation Action Plan (eds R. Woodroffe, J.R. Ginsberg \& D. Macdonald), pp. 100-111. IUCN/SSC Canid Specialist Group. IUCN, Gland, Switzerland.

Woodroffe, R. \& Ginsberg, J.R. (1999) Conserving the African wild dog Lycaon pictus. II. Is there a role for reintroduction? Oryx, 33, 143-151.

Woodroffe, R., Ginsberg, J.R. \& Macdonald, D. (eds) (1997) The African Wild Dog-Status Survey and Conservation Action Plan. IUCN/Species Survival Commission, Canid Specialist Group, IUCN, Gland, Switzerland.

Yalden, D.W. (1993) The problems of reintroducing carnivores. In Mammals as Predators (eds N. Dunstone \& M.L. Gorman). Symposium of the Zoological Society of London, 65, 289-306.

\section{Appendix}

The appendix for this article is available online at http:// journals. cambridge.org

\section{Biographical sketches}

Harriet Davies' research interests include metapopulation ecology of large carnivores, and in particular the challenges involved with carnivore reintroductions. She has participated in developing national guidelines for wild dog management for the Wild Dog Advisory Group, South Africa, of which she is a member.

Johan du Toit's research focus is the ecology of large mammals in African savannah and he also maintains an academic involvement in the issues and challenges associated with conserving African wildlife against a backdrop of human population growth and poverty. 